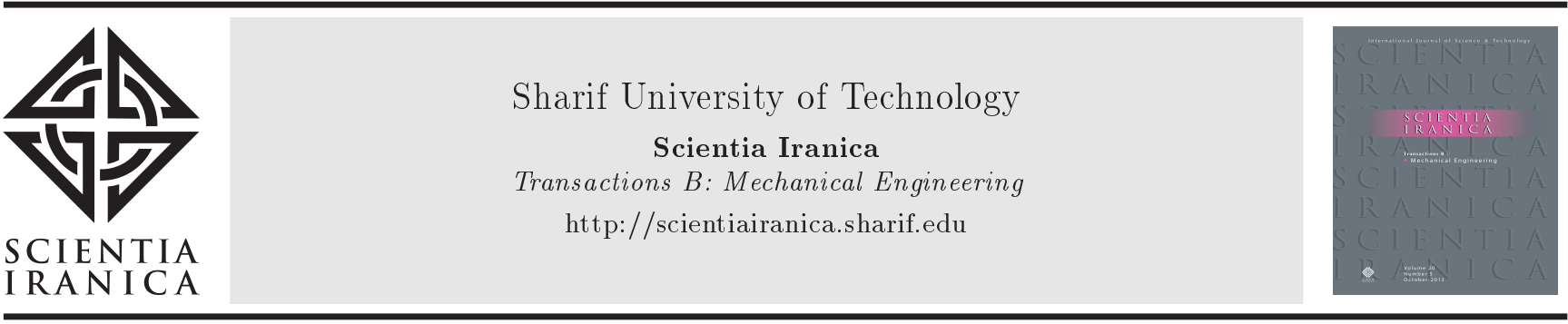

\title{
Minimizing the casting defects in high-pressure die casting using Taguchi analysis
}

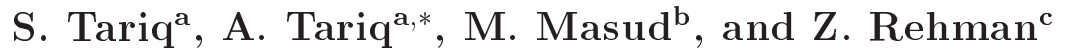 \\ a. Department of Mechanical Engineering, Wah Engineering College, University of Wah, Wah Cantt, 47040, Pakistan. \\ b. Department of Mechanical Engineering, Capital University of Science and Technology, Islamabad, 44000, Pakistan. \\ c. Department of Mechanical Engineering, Air University Islamabad, Aerospace and Aviation Campus, Kamra 43570, Pakistan.
}

Received 4 August 2020; received in revised form 7 April 2021; accepted 24 May 2021

\section{KEYWORDS}

High pressure die casting;

Porosity;

Design of experiment;

Optimization;

Casting defects.

\begin{abstract}
High-Pressure Die Casting (HPDC) is one of the major production processes of the automotive industry, widely used to manufacture geometrically complex nonferrous castings. The mechanical strength and microstructure of HPDC-manufactured products change with variation in several process parameters such as injection pressure, molten temperature, 1st and 2nd stage plunger velocities, cooling temperature, etc. Since these process parameters directly affect casting quality, their optimum combination is needed to maximize productivity of the process and minimize casting defects such as porosity, pinholes, blowholes, etc. Hence, to tackle this problem, an approach is presented in this paper that minimizes the major casting defect, i.e., porosity, in the HPDC process by optimizing parameters through Design Of Experiments (DOE) in combination with Taguchi Analysis. The obtained results showed that cooling time, injection pressure, and 2nd stage plunger velocity had a major influence on the response factor (density of the cast part). It was further concluded that by using a 178-bar injection pressure, $665^{\circ} \mathrm{C}$ molten temperature, 5 seconds of cooling time, $210^{\circ} \mathrm{C}$ mold temperature, $0.20 \mathrm{~m} . \mathrm{s}^{-1} 1$ st stage plunger velocity, and $6.0 \mathrm{~m} . \mathrm{s}^{-1}$ 2nd stage plunger velocity, the rejection rate of the selected part due to porosity was reduced by $61 \%$.
\end{abstract}

(C) 2022 Sharif University of Technology. All rights reserved.

\section{Introduction}

High-Pressure Die Casting (HPDC) is one of the most prominent and broadly used manufacturing processes to produce economical, complex-shaped and dimensionally precise non-ferrous metal parts such as aluminum [1,2]. It is used to manufacture a broad range of parts for the automotive industry, for instance,

\footnotetext{
*. Corresponding author. Tel.: +92345 8555323;

Fax: +92 519314391

E-mail addresses: surkhailch@gmail.com (S. Tariq);

adnan.tariq@wecuw.edu.pk (A.Tariq);

manzar.masud@cust.edu.pk (M. Masud);

zabdurrehman@au.edu.pk(Z.Rehman)
}

doi: 10.24200 /sci. 2021.56545 .4779 clutches, gear boxes, suspensions, brake parts, connecting rods, etc. [3]. In addition to the automotive sector, HPDC is also used to manufacture parts for other industrial fields such as telecommunication and agriculture $[4,5]$.

Generally, in HPDC, the molten metal is prepared and forced through a sleeve under high pressure into the die cavity, where it is held under high pressure until the solidification occurs. After the solidification of the metal, the die is unconstrained and the casting is ejected [6]. The HPDC process results in superior production of parts, with higher dimensional accuracy and reduced manufacturing cost per part [4]. Even though the process has many advantages, the final castings still always have defects such as porosity, pinholes, blowholes, shrinkage, inclusions, and ring 
cracks $[4,5,7]$. Such defects, in addition to directly affecting the tensile and fatigue strengths, also adversely influence the machinability and surface finish of the cast parts $[5,8-10]$.

The quality of the parts produced through HPDC for different applications such as automotive and telecommunication depends upon various controlling parameters, some of which are manageable and some are noise factors $[5,11-13]$. Each one of these parameters must be set to its optimized value in order to achieve perfect solidification and parts without casting defects. Among these controlling parameters, injection pressure is a major contributing factor in porosity, as the change in porosity has a linear relationship with negative pressure in the die cavity [14-16]. Additionally, a non-uniform cooling temperature results in the formation of shrinkage defects [17]. Variations in the pouring temperature, casting pressures, and 1st and 2nd stage plunger velocities result in changing the metallurgical properties and mechanical strength of the cast parts [18]. Plunger velocity and its motion play an important role in the final quality of the die castings. The 1st stage plunger velocity is linked to the filling of die casting chamber in machine, whereas the 2 nd stage plunger velocity is correlated with filling of the die cavity [19]. Air entrapment defects occur normally during the heat treatment process due to variations in the cooling temperature while dealing with the A380 alloy [20]. The solidification behavior during filling has a very significant effect on surface defects. The rate of decrease in the temperature of the molten metal in the die affects the probability of surface defects, and it increases with the increase in thickness of the solid surface layer [21]. Similarly, the die temperature affects the quality of products in HPDC, and any deviation from the optimum range results in casting defects $[22,23]$. The 1 st and 2 nd stage plunger profiles and velocity play a significant role in decreasing the strength properties of castings in case of Aluminum alloys [19]. These are the reasons that require a combination of different HPDC process control parameters (injection pressure, molten temperature, 1st and 2nd stage plunger velocities, casting pressures, cooling temperature, and die cooling time) to be optimized to produce high-quality castings with minimum defects. Several such studies, either simulation-based or experimental, have been performed and reported in literature [7,24]. For instance, Fajkiel et al. [25] used computer simulations of the die filling process and solidification to assist the foundry men to overcome the occurrence of major defects in die casting, e.g., porosity, cracks, and blow holes. The major purpose of the computer simulation was to rectify the design of the mold and process parameters. Swillo and Myszka [26] developed a system based on an artificial neural network for online inspection of surface defects such as porosity, cracks, and blow holes in die cast products. Cica and Kramar [27] developed a predictive model for minimizing the porosity of cast parts using fuzzy systems based on Simulated Annealing and Genetic Algorithms. Cao et al. [28] used "Anycasting" software to accurately predict the porosity distribution by simulating the actual filling process of HPDC.

All the studies discussed above show that various attempts have been made to investigate the effects of different controlling parameters on the die casting process. It can also be concluded from these studies that the outcome of all these process parameters is significantly complex in the case of HPDC. Therefore, the assortment of suitable process control parameters for manufacturing a high-quality part through die casting remains one of the major challenges. The most conventional method used in the foundries' environment is the trial and error method due to its ease of application [29]. However, the effectiveness of this method requires extensive experimentation that leads to a decrease in productivity and increase in cost. A significant decrease in the number of experiments can be attained using the technique of Design of Experiments (DOE) in complex and multi-variable manufacturing processes. Among the different approaches, Taguchi, in combination with DOE, has been extensively used to optimize the controlling parameters of various processes [30-34]. For instance, Karthik et al. [35] used the Taguchi method to optimize the process parameters of squeeze casting for Aluminum alloy (AA219). Hardness and density were selected as response variables. It was found that a pressure of $650 \mathrm{MPa}$, die preheating temperature of $225^{\circ} \mathrm{C}$, and melting temperature of $700^{\circ} \mathrm{C}$ produced an improved mechanical response. Similarly, Hassasi et al. [36] and Souissi et al. [37] investigated the effects of squeeze casting process parameters on the microstructure and mechanical properties of Aluminum alloy using a DOE approach based on the Taguchi method. Prabhakar et al. [38] used DOE, i.e., ANOVA, to identify the most significant process parameters during the formation of grooves manufactured by the sand casting process. An optimal set of parameters was proposed to minimize the defects of the final product. Mohsin et al. [39] used the Taguchi method and ANOVA to investigate the significance of various input polishing process parameters on the polishing efficiency and torque in a robotic polishing system.

All these studies point out that the Taguchi method has been used for optimizing the process parameters for manufacturing processes. However, it is evident that a limited number of investigators have focused on finding an approach that synchronizes the connection between various manufacturing defects and the quality enhancement of products in an application 
where these defects cannot be completely eradicated. Indeed, a comprehensive approach considering most of the significant parameters is missing in literature. With this motivation, an approach is developed during this research that considers various controlling parameters (injection pressure, molten metal temperature, die cooling time, mold temperature, and 1st and 2nd stage plunger velocities) and optimizes the HPDC process by DOE in combination with the Taguchi analysis.

\section{Methodology}

To conduct this research, a motorbike manufacturing company was selected in Lahore (Pakistan) which has been manufacturing motorbikes of $100 \mathrm{cc}$ engine capacity for the last seven years. The company was consistently facing the problems of parts rejection at the die casting stage of their production line. To identify the root cause and propose a solution, the experimental procedure adopted during this research is outlined as follows:

- Analysis of the die casting procedure:

a) Identifying the part that was most frequently produced (cast);

b) Identification of defects causing frequent rejections of the selected part.

- DOE - Taguchi robust experimentation:

a) Selection of the input variables/factors;

b) Selection of the response factor;

c) Setting parameters for ranges and levels;

d) Selection of Orthogonal Arrays (OA).

- Experimental procedure:

a) Performing experiments as per DOE;

b) Acquisition of the response factor data.

\subsection{Analysis of the die casting procedure}

In order to identify the part that was produced through this process more frequently and the type of defect, which was responsible for its frequent rejection, the production data of the past one month were collected from the Aluminum die casting shop of the company. Only those parts whose production requirements were more than 10,000 units per month were selected. The collected data are given in Table 1.

Based on the collected production data, "Crankcase Left Hand (LH)", shown in Figure 1, was selected for the proposed experimental and statistical study due to its many production requirements.

The material composition of Crankcase LH was found by using Spectromax metal analyzer machine and is shown in Table 2. The calibration of the Spectromax metal analyzer was performed by using completely defined calibration modules for the relevant
Table 1. Production data of Al-HPDC shop (one-month data).

\begin{tabular}{clc}
\hline Serial no. & \multicolumn{1}{c}{ Part name } & $\begin{array}{c}\text { Monthly } \\
\text { production } \\
\text { quantity } \\
\text { (Qty.) }\end{array}$ \\
\hline 1 & Crankcase Left Hand (LH) & 48,570 \\
2 & Crankcase Right Hand (RH) & 43,600 \\
3 & Crankcase cover left & 42,800 \\
4 & Crankcase cover right & 35,132 \\
5 & Cover cylinder head & 12,100 \\
6 & Crankcase LH 100cc & 10,500 \\
7 & Crankcase RH 100cc & 10,800 \\
8 & Housing oil seal & 10,100 \\
\hline
\end{tabular}

Table 2. Material composition of aluminum alloy used for Crankcase LH.

\begin{tabular}{cccccccc}
\hline $\mathrm{Si} \%$ & $\mathrm{Fe} \%$ & $\mathrm{Cu \%}$ & $\mathrm{Mn} \%$ & $\mathrm{Mg} \%$ & $\mathrm{Ni} \%$ & $\mathrm{Zn \%}$ & $\mathrm{Sn \%}$ \\
\hline 9.5 & 2.0 & 0.6 & 0.35 & 0.5 & 0.5 & 0.5 & 0.15 \\
\hline
\end{tabular}

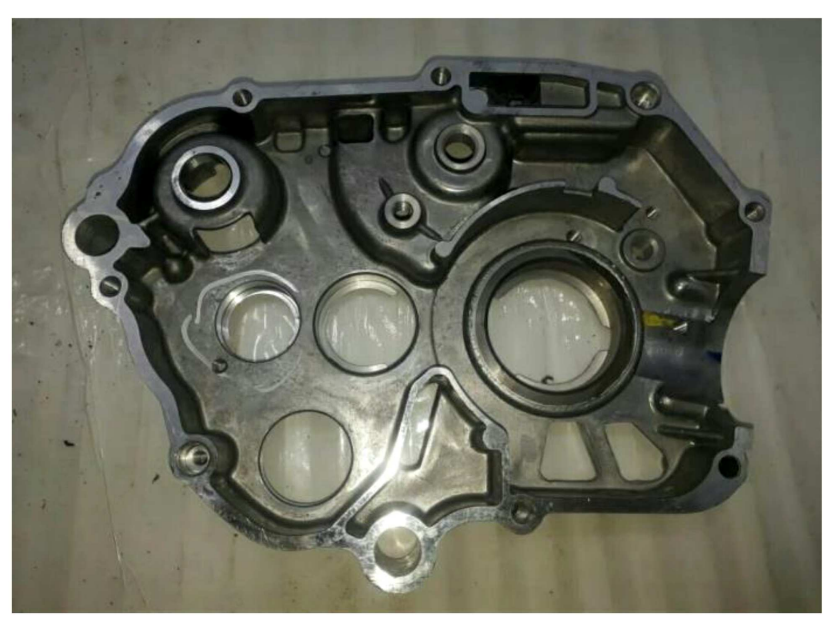

Figure 1. Crankcase specimen produced with the High-Pressure Die Casting (HPDC) process.

matrices (base metals) like $\mathrm{Fe}, \mathrm{Al}, \mathrm{Cu}, \mathrm{Ni}, \mathrm{Co}, \mathrm{Ti}$, $\mathrm{Mg}, \mathrm{Zn}, \mathrm{Sn}$, and $\mathrm{Pb}$; it is updated regularly by the manufacturing company.

Then, for the purpose of identifying the casting defect responsible for the frequent rejections of Crankcase LH, the casting data were collected in the shop for one month. This consequently helped in determining the rejection quantity and percentage of its corresponding reasons. During this time, the total number of 48,570 samples (total sample size) was checked. Check sheets were prepared for data collection while highlighting the most recurrent defects. The associated defects, along with rejected quantities and their respective percentages, are presented in Table 3 . The percentage of each individual defect, listed in Ta- 
Table 3. Number of rejected quantities and associated defects of the selected part.

\begin{tabular}{clccc}
\hline Sr. no & \multicolumn{1}{c}{ Defects } & Rejected qty. & $\begin{array}{c}\text { Rejected qty. } \\
\text { percentage }\end{array}$ & $\begin{array}{c}\text { Defects } \\
\text { percentage }\end{array}$ \\
\hline 1 & Pin hole/blow hole & 435 & $0.9 \%$ & $32.17 \%$ \\
2 & Crack & 239 & $0.49 \%$ & $17.68 \%$ \\
3 & Shrinkage & 189 & $0.39 \%$ & $13.98 \%$ \\
4 & Inclusion & 167 & $0.34 \%$ & $12.35 \%$ \\
5 & Dents & 121 & $0.25 \%$ & $8.95 \%$ \\
6 & Ring crack/mismatch & 112 & $0.23 \%$ & $8.28 \%$ \\
7 & Shade & 89 & $0.18 \%$ & $6.59 \%$ \\
\hline
\end{tabular}

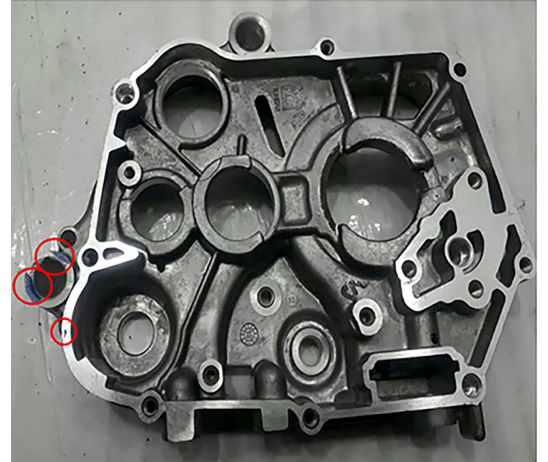

(a)

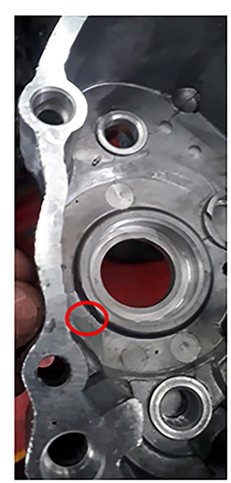

(b)
Figure 2. Casting defects found in the Crankcase: (a) pinhole and (b) porosity.

ble 3, was calculated using the total rejected samples, i.e., 1352. The data presented in Table 3 clearly shows that porosity remains a major defect, causing rejection of 435 samples and amounting to the overall rejection percentage of $0.9 \%$.

To further elaborate some of the casting defects found while producing the Crankcase specimen, in the HPDC process, some images of the actual part are displayed in Figure 2.

To highlight the significance of different defects listed in Table 3, the collected data have also been plotted on a Pareto diagram, as shown in Figure 3. It is evident both from Table 3 and Figure 3 that porosity and blow holes are the major defects, because they have the highest rejection percentage of $32.17 \%$ and are, therefore, the major cause of production loss and poor quality.

\subsection{DOE - Taguchi robust experimentation}

DOE is a systematic statistical approach to determine the effects of input parameters on a process and it helps designers obtain maximum information with the minimum utilization of resources. While implementing this technique during this research, structured tests were designed and performed, during which planned modifications were made for the input variables of the system/process. Different input variables were selected to analyze output of the process. The following are the major steps that were followed during the course of this research:

1. Identification and selection of the factors (input variables);

2. Selection of response of the system/process (output variables);

3. Setting up of the levels for factors;

4. Conducting and documenting experiments;

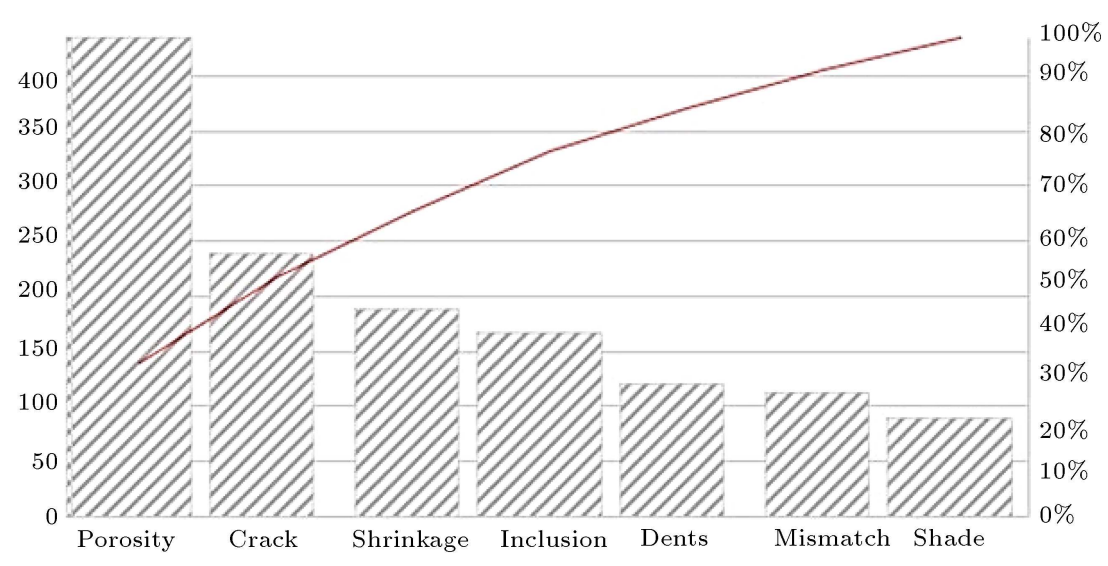

Figure 3. Pareto chart of the defects. 


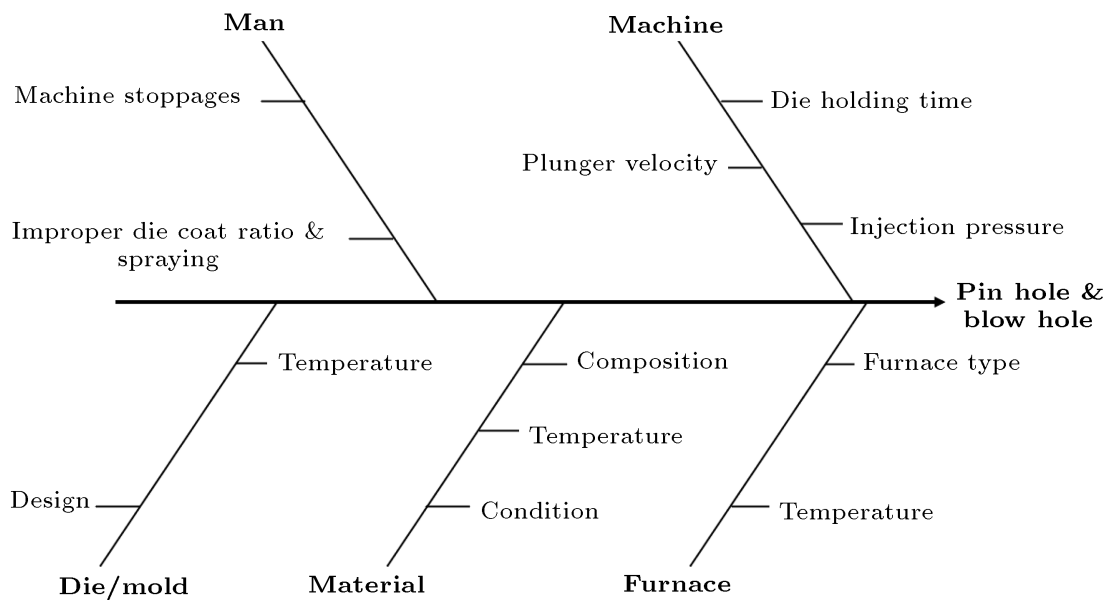

Figure 4. Cause and effect diagram.

5. Comparison of DOE and experimental results for validation.

To design the experiments, it is essential to first identify the relevant factors (process parameters) for better product quality. For this purpose, a "root cause analysis" was carried out using a fishbone diagram, as shown in Figure 4. From the diagram (Figure 4), the factors that caused porosity were identified. Out of the total identified parameters causing porosity, the following six were selected as they could be controlled in the foundry:

1. Injection pressure (bar);

2. Molten temperature $\left({ }^{\circ} \mathrm{C}\right)$;

3. Die cooling time (s);

4. Mold temperature $\left({ }^{\circ} \mathrm{C}\right)$;

5. 1st stage plunger velocity $\left(\mathrm{m} . \mathrm{s}^{-1}\right)$;

6. 2nd stage plunger velocity $\left(\mathrm{m} . \mathrm{s}^{-1}\right)$.

To assess the number of selected defects (pin holes and porosity), density was chosen as the major response factor being a continuous and controllable factor.

The standard density of Aluminum ADC 12 is 2.75 g.cm ${ }^{-3}$ [40]. Thus, if the density of the part is 2.75 g. $\mathrm{cm}^{-3}$ or closer to this value, it may mean that the produced part has fewer pin holes and lower porosity. Initial trials were performed on the selected part to determine the ranges and levels of the selected factors, as shown in Table 4.

It is important to determine the Degrees Of Freedom (DOF) before selecting OA because the minimum number of required experiments shall be determined by using the DOF. The minimum number of experiments that needs to be run to investigate the selected factors shall be greater than the total available DOF [41]. Literature review indicates that the Taguchi method facilitates the calculation of DOF using the methods of with and without coupled interactions between selected factors $[33,41,42]$. However, in this study, coupled effects of selected controlling parameters and their interactions have not been investigated.

DOF is basically the number of comparisons between processes and defined levels. For this research: number of factors is 6 , number of levels is 3 , and overall mean is 1 . DOF is given by Eq. (1):

$$
\begin{aligned}
\mathrm{DOF}= & \text { Number of factors } \\
& \times(\text { Number of levels }- \text { Overall mean }), \\
\text { DOF }= & 6 \times(3-1)=12 .
\end{aligned}
$$

Thus, 12 DOF is available with no interaction between the parameters. The best fit OA for the DOE was $\mathrm{L}_{27}$

Table 4. Ranges of selected factors.

\begin{tabular}{clccccc}
\hline Sr. no & \multicolumn{1}{c}{ Factors } & Units & Range & Level 1 & Level 2 & Level 3 \\
\hline 1 & Injection pressure-A & Bar & $180-200$ & 180 & 190 & 200 \\
2 & Molten temperature-B & ${ }^{\circ} \mathrm{C}$ & $640-670$ & 640 & 655 & 670 \\
3 & Die cooling time-C & $\mathrm{s}$ & $4.0-6.0$ & 4.0 & 5.0 & 6.0 \\
4 & Mold temperature-D & ${ }^{\circ} \mathrm{C}$ & $190-210$ & 190 & 200 & 210 \\
5 & 1st stage-plunger velocity-E & ${\mathrm{m} . \mathrm{s}^{-1}}^{-1}$ & $0.2-0.3$ & 0.2 & 0.25 & 0.3 \\
6 & 2nd stage-plunger velocity-F & $\mathrm{m} . \mathrm{s}^{-1}$ & $5.0-7.0$ & 5.0 & 6.0 & 7.0 \\
\hline
\end{tabular}


[43], which had a maximum of 13 factors with 3 levels and 26 DOF.

A total number of 27 experiments (combinations) were found using Minitab 2018 through the Taguchi DOE, as shown in Table 5. The experimental setup consisted of an 800-ton HPDC machine (Yizumi SM$800 \mathrm{~T}$, made in China) equipped with an auto sprayer, auto ladle, gas melting and holding furnace, and mold of the selected part. To determine the machine efficiency, its maintenance records were checked and the value was found above $85 \%$. The mold was initially preheated to a temperature of $180^{\circ} \mathrm{C}$ and then, further measurements were taken with the help of an infrared gun. In addition to proper gas removal from the molten material, slag was also removed from the surface of the furnace. Material samples were taken from the furnace and the composition was checked using a Spectro machine. Initially, casting of 35 parts was carried out to check whether the machine was working properly or not. Each casting was termed as a shot. Three shots were taken against each combination of the selected parameters, as declared by the DOE, and properly marked to avoid mixing. The whole process resulted in 81 castings of the selected part. The cast parts were dispatched to the deburring section for removal of burrs and extra material.

The mass of each cast part was measured using electronic weighing scale that had the least count of $1 \mathrm{~g}$. The calibration of the weight scale was performed by using standard $5 \mathrm{gm}$ weight provided

Table 5. Experimental design $\left(L_{27}\right)$.

\begin{tabular}{|c|c|c|c|c|c|c|}
\hline \multirow[b]{2}{*}{$\begin{array}{c}\text { No. of } \\
\text { experiment }\end{array}$} & \multicolumn{6}{|c|}{ Selected factors } \\
\hline & $\begin{array}{c}\text { Injection } \\
\text { pressure } \\
\text { (bar) } \\
\text { A }\end{array}$ & $\begin{array}{c}\text { Molten } \\
\text { temperature } \\
\left({ }^{\circ} \mathrm{C}\right) \\
\mathrm{B}\end{array}$ & $\begin{array}{c}\text { Die cooling } \\
\text { time } \\
(\mathrm{s}) \\
\mathrm{C}\end{array}$ & $\begin{array}{c}\text { Mold } \\
\text { temperature } \\
\left({ }^{\circ} \mathrm{C}\right) \\
\text { D }\end{array}$ & $\begin{array}{c}\text { 1st stage } \\
\text { PV } \\
\left(\mathrm{m} . \mathrm{s}^{-1}\right) \\
\mathrm{E}\end{array}$ & $\begin{array}{c}\text { 2nd stage } \\
\text { PV } \\
\left(\mathrm{m} . \mathrm{s}^{-1}\right) \\
\mathrm{F}\end{array}$ \\
\hline 1 & 180 & 650 & 4.0 & 140 & 0.20 & 5.0 \\
\hline 2 & 180 & 650 & 4.0 & 140 & 0.25 & 6.0 \\
\hline 3 & 180 & 650 & 4.0 & 140 & 0.30 & 7.0 \\
\hline 4 & 180 & 660 & 5.0 & 180 & 0.20 & 5.0 \\
\hline 5 & 180 & 660 & 5.0 & 180 & 0.25 & 6.0 \\
\hline 6 & 180 & 660 & 5.0 & 180 & 0.30 & 7.0 \\
\hline 7 & 180 & 670 & 6.0 & 220 & 0.20 & 5.0 \\
\hline 8 & 180 & 670 & 6.0 & 220 & 0.25 & 6.0 \\
\hline 9 & 180 & 670 & 6.0 & 220 & 0.30 & 7.0 \\
\hline 10 & 190 & 650 & 5.0 & 220 & 0.20 & 6.0 \\
\hline 11 & 190 & 650 & 5.0 & 220 & 0.25 & 7.0 \\
\hline 12 & 190 & 650 & 5.0 & 220 & 0.30 & 5.0 \\
\hline 13 & 190 & 660 & 6.0 & 140 & 0.20 & 6.0 \\
\hline 14 & 190 & 660 & 6.0 & 140 & 0.25 & 7.0 \\
\hline 15 & 190 & 660 & 6.0 & 140 & 0.30 & 5.0 \\
\hline 16 & 190 & 670 & 4.0 & 180 & 0.20 & 6.0 \\
\hline 17 & 190 & 670 & 4.0 & 180 & 0.25 & 7.0 \\
\hline 18 & 190 & 670 & 4.0 & 180 & 0.30 & 5.0 \\
\hline 19 & 200 & 650 & 6.0 & 180 & 0.20 & 7.0 \\
\hline 20 & 200 & 650 & 6.0 & 180 & 0.25 & 5.0 \\
\hline 21 & 200 & 650 & 6.0 & 180 & 0.30 & 6.0 \\
\hline 22 & 200 & 660 & 4.0 & 220 & 0.20 & 7.0 \\
\hline 23 & 200 & 660 & 4.0 & 220 & 0.25 & 5.0 \\
\hline 24 & 200 & 660 & 4.0 & 220 & 0.30 & 6.0 \\
\hline 25 & 200 & 670 & 5.0 & 140 & 0.20 & 7.0 \\
\hline 26 & 200 & 670 & 5.0 & 140 & 0.25 & 5.0 \\
\hline 27 & 200 & 670 & 5.0 & 140 & 0.30 & 6.0 \\
\hline
\end{tabular}


Table 6. Densities of the samples cast in each experiment.

\begin{tabular}{|c|c|c|c|c|}
\hline $\begin{array}{c}\text { Experiment } \\
\text { no. }\end{array}$ & $\begin{array}{c}\text { Density (Sample 1) } \\
\left(\mathrm{g} \mathrm{m}^{-3}\right)\end{array}$ & $\begin{array}{c}\text { Density (Sample 2) } \\
\left(\mathrm{g} \mathrm{m}^{-3}\right)\end{array}$ & $\begin{array}{c}\text { Density (Sample 3) } \\
\left(\mathrm{g} \mathrm{m}^{-3}\right)\end{array}$ & $\begin{array}{c}\text { Density (Average) } \\
\left(\mathrm{g} \mathrm{m}^{-3}\right)\end{array}$ \\
\hline 1 & 2.510 & 2.505 & 2.500 & 2.505 \\
\hline 2 & 2.397 & 2.392 & 2.390 & 2.393 \\
\hline 3 & 2.569 & 2.544 & 2.542 & 2.552 \\
\hline 4 & 2.507 & 2.492 & 2.490 & 2.496 \\
\hline 5 & 2.510 & 2.501 & 2.499 & 2.503 \\
\hline 6 & 2.196 & 2.116 & 2.114 & 2.142 \\
\hline 7 & 2.296 & 2.206 & 2.191 & 2.231 \\
\hline 8 & 2.512 & 2.507 & 2.505 & 2.508 \\
\hline 9 & 2.571 & 2.569 & 2.567 & 2.569 \\
\hline 10 & 2.397 & 2.396 & 2.392 & 2.395 \\
\hline 11 & 2.397 & 2.394 & 2.389 & 2.393 \\
\hline 12 & 2.027 & 2.022 & 2.021 & 2.023 \\
\hline 13 & 2.107 & 2.102 & 2.100 & 2.103 \\
\hline 14 & 2.026 & 2.001 & 1.999 & 2.009 \\
\hline 15 & 2.026 & 2.011 & 2.009 & 2.015 \\
\hline 16 & 2.510 & 2.501 & 2.499 & 2.503 \\
\hline 17 & 2.515 & 2.435 & 2.433 & 2.461 \\
\hline 18 & 2.560 & 2.470 & 2.455 & 2.495 \\
\hline 19 & 2.196 & 2.191 & 2.189 & 2.192 \\
\hline 20 & 2.107 & 2.102 & 2.100 & 2.103 \\
\hline 21 & 2.607 & 2.602 & 2.600 & 2.603 \\
\hline 22 & 2.571 & 2.566 & 2.564 & 2.567 \\
\hline 23 & 2.569 & 2.564 & 2.562 & 2.565 \\
\hline 24 & 2.501 & 2.496 & 2.494 & 2.497 \\
\hline 25 & 2.508 & 2.503 & 2.501 & 2.504 \\
\hline 26 & 2.292 & 2.287 & 2.285 & 2.288 \\
\hline 27 & 2.392 & 2.387 & 2.385 & 2.388 \\
\hline
\end{tabular}

by its manufacturer. Eccentricity, repeatability, and weighing tests were performed regularly to calibrate the weighing instrument. Using Archimedes' principle, the density of the sample was measured according to the weight of sample in air, the weight of the sample in liquid, and the density of the liquid. The calibration of the measuring instrument was performed by comparing the measured density with the standard density of the sample provided by the industrial partner, i.e., 2.75 g.cm ${ }^{-3}$. After determining density, material inspection was performed by the quality and machining department and the parts with a density less than the standard density were rejected. The machining department then determined the type of casting defect, e.g., porosity, pinhole, blowhole, etc.

The calculated density values are listed in Table 6 .

\section{Results and discussion}

The process parameters of HPDC, i.e., injection pressure, molten temperature, die cooling time, mold temperature, 1st stage plunger velocity, and 2nd stage plunger velocity, were optimized using the Taguchi analysis to determine the most significant of those affecting the density. The results obtained from the Taguchi analysis were then validated using experimental results obtained by varying each parameter to its optimum value while keeping others constant. The results, obtained during the experimentation and with the help of software (Minitab 18), were employed to determine the best combination of the selected factors.

\subsection{Taguchi analysis}

The Taguchi analysis is an approach to determine the best values for a set of parameters by using DOE to improve the overall quality of the products $[42,44,45]$. The following approaches were used to find the optimum values of the selected parameters:

1. Analysis of response with respect to mean;

2. Analysis of response with respect to Signal-to-Noise $(S / N)$ ratio. 
Table 7. Response table of the means.

\begin{tabular}{ccccccc}
\hline Level & $\begin{array}{c}\text { Injection } \\
\text { pressure }\end{array}$ & $\begin{array}{c}\text { Molten } \\
\text { temperature }\end{array}$ & $\begin{array}{c}\text { Cooling } \\
\text { time }\end{array}$ & $\begin{array}{c}\text { Mold } \\
\text { temperature }\end{array}$ & $\begin{array}{c}\text { 1st stage-plunger } \\
\text { velocity }\end{array}$ & $\begin{array}{c}\text { 2nd stage-plunger } \\
\text { velocity }\end{array}$ \\
\hline 1 & 2.433 & 2.351 & 2.504 & 2.306 & 2.388 & 2.302 \\
2 & 2.266 & 2.322 & 2.348 & 2.389 & 2.358 & 2.433 \\
3 & 2.412 & 2.439 & 2.259 & 2.416 & 2.365 & 2.377 \\
Delta & 0.167 & 0.117 & 0.245 & 0.110 & 0.030 & 0.130 \\
Rank & 2 & 4 & 1 & 5 & 6 & 3 \\
\hline
\end{tabular}

\subsubsection{Analysis of response with respect to mean}

The Taguchi analysis for the mean values is given in Table 7 .

Here, delta represents the difference between the maximum and the minimum values of response and rank is the corresponding order of effect for each factor. The higher the value of delta, the higher the rank. The results imply that cooling time (1), injection pressure (2), 2nd stage plunger velocity (3), and molten temperature (4) significantly affect the density of the product. The graphs of the mean values against each input parameter are shown in Figure 5.

3.1.2. Analysis of response with respect to $S / N$ ratio To maximize the response, the $S / N$ ratio was calculated using Eq. (2):

$$
\text { Larger the better }=-10 \times \log \left[\frac{1}{n} \sum \frac{1}{Y^{2}}\right],
$$

where $n$ is the number of observations and $Y$ is the response value of each trail. A larger value of the density means that the product has fewer pin holes. Response for the $S / N$ ratios is presented in Table 8 .

The Taguchi analysis of the $S / N$ ratios, as shown in Table 8, concluded that the cooling time (1), injection pressure (2), 2nd stage plunger velocity (3), and molten temperature (4) significantly affect the density of the part. The variation in means of the $S / N$ ratios against each input parameter is illustrated in Figure 6.

\subsubsection{Optimized parameters with Taguchi analysis}

The Taguchi analysis of means (Table 7 ), $S / N$ ratios (Table 8), and their corresponding main effect plots (Figures 5 and 6, respectively) determined that the cooling time, injection pressure, and 2nd stage plunger velocity were the parameters that significantly impacted the occurrence of porosity while using HPDC during this research.

The effect of the die cooling time on porosity has been elaborated in Figure 5. It clearly shows that enhancing the die cooling time resulted in increasing the level of porosity, which consequently decreased the density of the respective part. Experience confirms that the most common cause of porosity is the nonuniform cooling of the part inside the cavity, which generally occurs when an unsuitable duration of time is allowed for cooling. The shrinkage rate during solidification is mostly affected by varying the cooling time and temperature. Following the same trend, it

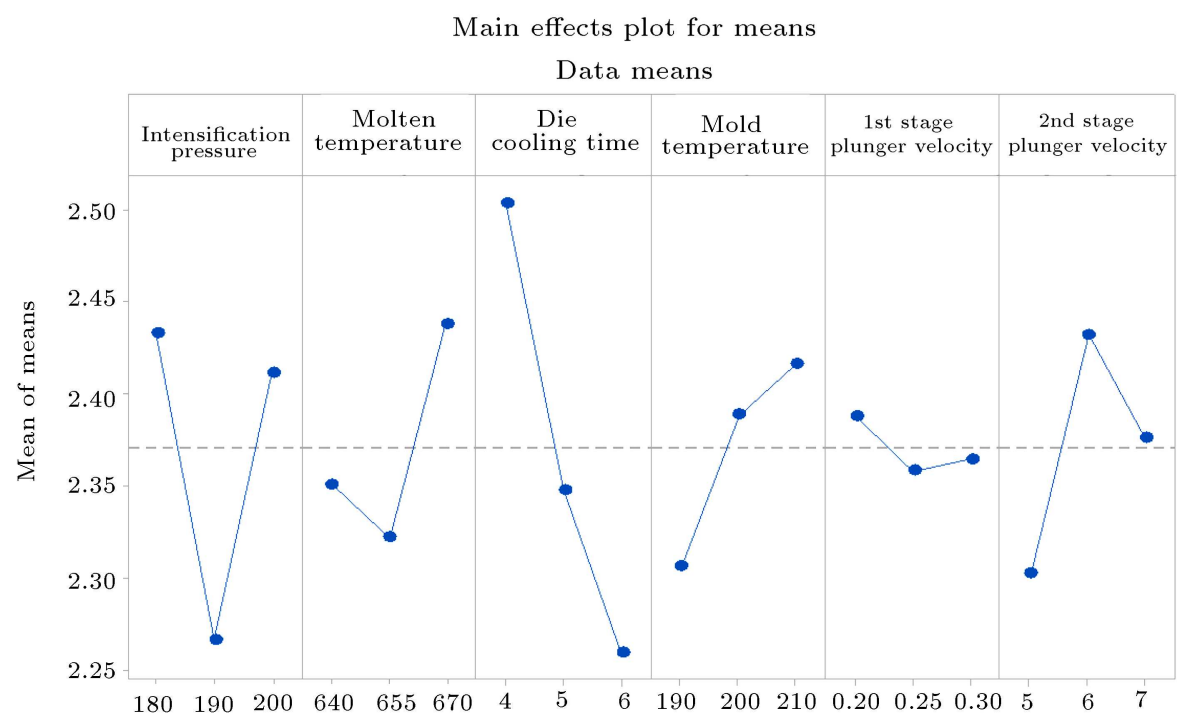

Figure 5. Response graph of means against the selected input parameters. 
Table 8. Response table of the $S / N$ ratios.

\begin{tabular}{ccccccc}
\hline Level & $\begin{array}{c}\text { Injection } \\
\text { pressure }\end{array}$ & $\begin{array}{c}\text { Molten } \\
\text { temperature }\end{array}$ & $\begin{array}{c}\text { Cooling } \\
\text { time }\end{array}$ & $\begin{array}{c}\text { Mold } \\
\text { temperature }\end{array}$ & $\begin{array}{c}\text { 1st stage-plunger } \\
\text { velocity }\end{array}$ & $\begin{array}{c}\text { 2nd stage-plunger } \\
\text { velocity }\end{array}$ \\
\hline 1 & 7.708 & 7.396 & 7.972 & 7.224 & 7.542 & 7.207 \\
2 & 7.069 & 7.272 & 7.393 & 7.538 & 7.425 & 7.707 \\
3 & 7.635 & 7.734 & 7.037 & 7.639 & 7.435 & 7.488 \\
Delta & 0.639 & 0.462 & 0.934 & 0.415 & 0.118 & 0.500 \\
Rank & 2 & 4 & 1 & 5 & 6 & 3 \\
\hline
\end{tabular}

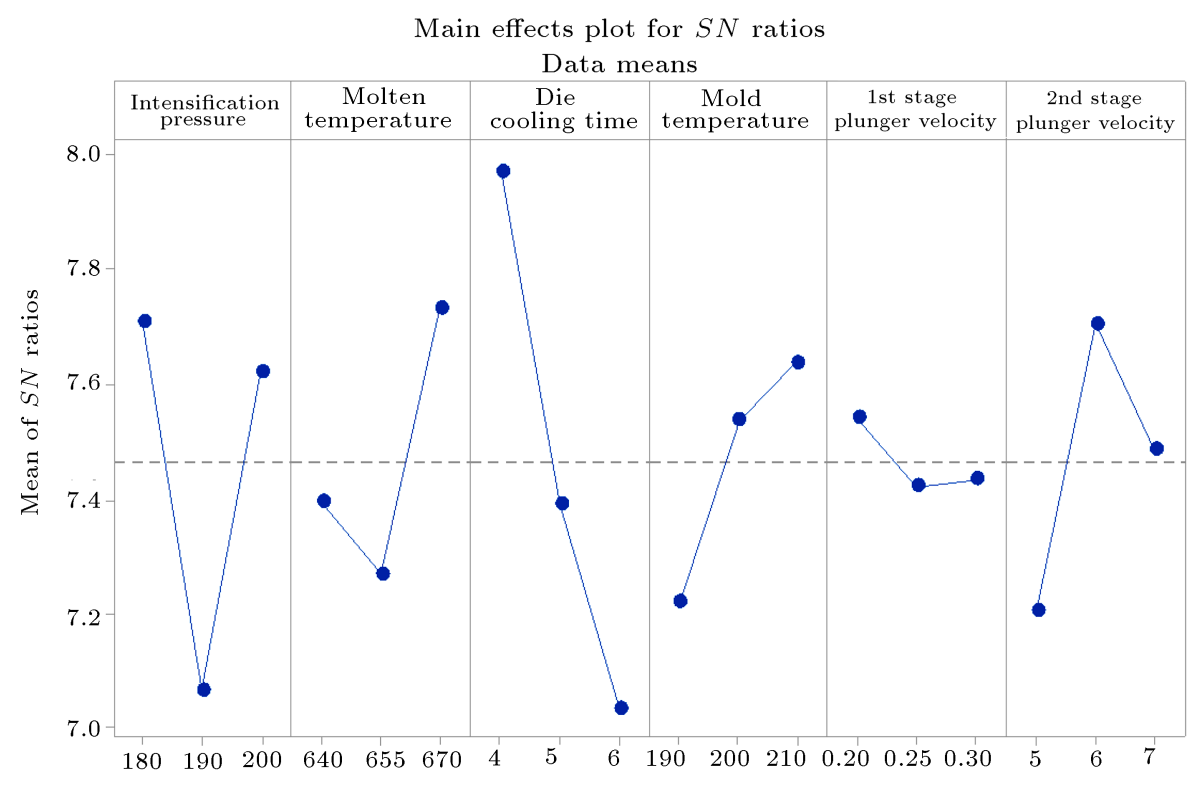

Signal-to-noise: Larger is better

Figure 6. Response graph of the $S / N$ ratio against the selected input parameters.

can be clearly observed in Figures 5 and 6 that the maximum values of mean density and $S / N$ ratios are achieved when allowing a cooling time of $4 \mathrm{~s}$.

The next significant parameter affecting the formation of porosity in HPDC is the injection pressure, as evident in Tables 7 and 8 . It mainly affects the volume of air entrapped in the sleeve while filling the cavity. Although a higher injection pressure results in decreasing gas inclusions and pores, it also induces additional stresses in castings. Therefore, by using the larger the better rule for the mean density (Figure 5 ) and $S / N$ ratios (Figure 6 ), it can clearly be concluded that the optimized value of injection pressure is 180 bar in this case.

The 2nd stage plunger velocity was found during this study as the third most significant source that affects the formation of porosity in HPDC. Figures 5 and 6 illustrate that the 1st stage plunger velocity has a trivial effect on the formation of porosity. However, the higher 2 nd stage plunger velocity results in porosity as it sprays the molten metal inside the cavity, thus dismissing the possibility of complete cavity filling in a smooth manner. In order to reduce this effect, the 2 nd stage plunger velocity is recommended to be kept as low as possible. The results in Figures 5 and 6 clearly depict that the optimized values of 1 st and 2 nd stage plunger velocities, according to the mean and $S / N$ ratio, are $0.20 \mathrm{~m} . \mathrm{s}^{-1}$ and $6.0 \mathrm{~m} . \mathrm{s}^{-1}$, respectively, while considering the larger the better rule.

Last of the substantial parameters that affects porosity, as far as this research is concerned, is the temperature of the molten metal and mold. Their impact on porosity is also demonstrated in Figures 5 and 6 . It can be observed that the occurrence of porosity can be decreased by increasing the temperature of molten metal and its subsequent mold. An analysis shows that a molten temperature of $670^{\circ} \mathrm{C}$ and a mold temperature of $210^{\circ} \mathrm{C}$ resulted in a lower percentage of porosity and higher corresponding value of density. The values of the optimized parameters according to the mean and $S / N$ ratios are listed in Table 9 .

\subsection{Experimental results of optimized parameters}

To validate the results of Taguchi analysis, experiments were performed by varying each parameter to its opti- 
Table 9. Optimized parameters, according to the mean and $S / N$ ratio analysis.

\begin{tabular}{clc}
\hline Sr. no & Input parameters & $\begin{array}{c}\text { Optimized } \\
\text { value }\end{array}$ \\
\hline 1 & Injection pressure & $180 \mathrm{bar}$ \\
2 & Molten temperature & $670^{\circ} \mathrm{C}$ \\
3 & Die cooling time & $4 \mathrm{~s}$ \\
4 & Mold temperature & $210^{\circ} \mathrm{C}$ \\
5 & 1st stage plunger velocity & $0.20 \mathrm{~m} \cdot \mathrm{s}^{-1}$ \\
6 & 2nd stage plunger velocity & $6.0 \mathrm{~m} \cdot \mathrm{s}^{-1}$ \\
\hline
\end{tabular}

mum value while keeping the others constant. The optimum range of each parameter was obtained from the means and $S / N$ plots to execute this step. According to Tables 7 and 8 , the cooling time had a major effect on the product quality, followed by injection pressure, 2nd stage plunger velocity, molten temperature, mold temperature, and 1st stage plunger velocity.

\subsubsection{Injection pressure}

Plots of the means and $S / N$ ratios against the injection pressure, as presented in Figures 5 and 6 , show that the maximum value of density is achieved at an injection pressure of 180 bar and subsequently, it shows a decreasing trend until 190 bar. It is also concluded from the plots that the range of optimum pressures is $170-180$ bars. While keeping this range in mind, the injection pressure was initiated with a value of 170 bar; then, the experiments were design and increments of 2 bar were used. The DOE to obtain the optimized injection pressure is listed in Table 10 .

As per the condition of the larger the better, Table 10 shows that the optimum value of injection pressure is 178 bar, as it results in the highest value of density with no defects.

\subsubsection{Molten temperature}

The molten temperature was observed to have a significant effect on the product quality. The graphs of molten temperature plotted against the means and $S / N$ ratios, as presented in Figures 5 and 6 , show a decreasing trend from $640^{\circ} \mathrm{C}$ to $655^{\circ} \mathrm{C}$, followed by an increasing trend until $670^{\circ} \mathrm{C}$ while intersecting the mean line at $660^{\circ} \mathrm{C}$. It can, therefore, be concluded that the optimum melting temperature lies between $655^{\circ} \mathrm{C}$ and $670^{\circ} \mathrm{C}$. To analyze the effect of the molten temperature accurately, the experiments began from $645^{\circ} \mathrm{C}$ and went up to $670^{\circ} \mathrm{C}$. The corresponding design of the experiments for optimum molten temperature is shown in Table 11.

From the data shown in Table 11, it is inferred that the optimum value of the molten temperature is $665^{\circ} \mathrm{C}$, because the mean line in Figures 5 and 6 is intersected at $660^{\circ} \mathrm{C}$ and a higher value of density $\left(2.590 \mathrm{~g} . \mathrm{cm}^{-3}\right)$ was obtained at temperatures greater than $660^{\circ} \mathrm{C}$.

Table 10. Optimization of the injection pressure.

\begin{tabular}{cccccccc}
\hline $\begin{array}{c}\text { Injection } \\
\text { pressure } \\
(\text { bar })\end{array}$ & $\begin{array}{c}\text { Molten } \\
\text { temperature } \\
\left({ }^{\circ} \mathbf{C}\right)\end{array}$ & $\begin{array}{c}\text { Cooling } \\
\text { time } \\
(\mathbf{s})\end{array}$ & $\begin{array}{c}\text { Mold } \\
\text { temperature } \\
\left({ }^{\circ} \mathbf{C}\right)\end{array}$ & $\begin{array}{c}\text { 1st stage } \\
\mathbf{P V} \\
\left(\mathbf{m . s}^{-\mathbf{1}}\right)\end{array}$ & $\begin{array}{c}\text { 2nd stage } \\
\mathbf{P V} \\
\left(\mathbf{m} . \mathbf{s}^{-\mathbf{1}}\right)\end{array}$ & $\begin{array}{c}\text { Density } \\
\left(\mathbf{g} \cdot \mathbf{m}^{-\mathbf{3}}\right)\end{array}$ & $\begin{array}{c}\text { Defects } \\
170\end{array}$ \\
670 & 4.0 & 180 & 0.20 & 6.0 & 2.490 & Pin holes \\
172 & 670 & 4.0 & 180 & 0.20 & 6.0 & 2.507 & Ok \\
174 & 670 & 4.0 & 180 & 0.20 & 6.0 & 2.510 & Ok \\
176 & 670 & 4.0 & 180 & 0.20 & 6.0 & 2.510 & Ok \\
178 & 670 & 4.0 & 180 & 0.20 & 6.0 & 2.569 & Ok \\
180 & 670 & 4.0 & 180 & 0.20 & 6.0 & 2.497 & Porosity \\
\hline
\end{tabular}

Table 11. Optimization of the molten temperature.

\begin{tabular}{cccccccc}
\hline $\begin{array}{c}\text { Injection } \\
\text { pressure } \\
(\mathbf{b a r})\end{array}$ & $\begin{array}{c}\text { Molten } \\
\text { temperature } \\
\left({ }^{\circ} \mathbf{C}\right)\end{array}$ & $\begin{array}{c}\text { Cooling } \\
\text { time } \\
(\mathbf{s})\end{array}$ & $\begin{array}{c}\text { Mold } \\
\text { temperature } \\
\left({ }^{\circ} \mathbf{C}\right)\end{array}$ & $\begin{array}{c}\text { 1st stage } \\
\mathbf{P V} \\
\left(\mathbf{m . s}^{-\mathbf{1}}\right)\end{array}$ & $\begin{array}{c}\text { 2nd stage } \\
\mathbf{P V} \\
\left(\mathbf{m . s}^{-\mathbf{1}}\right)\end{array}$ & $\begin{array}{c}\text { Density } \\
\left(\mathrm{g} \cdot \mathbf{m}^{-\mathbf{3}}\right)\end{array}$ & \begin{tabular}{c} 
Defects \\
\hline 178
\end{tabular} \\
645 & 4.0 & 180 & 0.20 & 6.0 & 2.501 & Misrun \\
178 & 650 & 4.0 & 180 & 0.20 & 6.0 & 2.562 & Misrun \\
178 & 655 & 4.0 & 180 & 0.20 & 6.0 & 2.584 & Ok \\
178 & 660 & 4.0 & 180 & 0.20 & 6.0 & 2.590 & Ok \\
178 & 665 & 4.0 & 180 & 0.20 & 6.0 & 2.590 & Ok \\
178 & 670 & 4.0 & 180 & 0.20 & 6.0 & 2.027 & Blow holes \\
\hline
\end{tabular}


Table 12. Optimization of the cooling time.

\begin{tabular}{cccccccc}
\hline $\begin{array}{c}\text { Injection } \\
\text { pressure } \\
(\mathbf{b a r})\end{array}$ & $\begin{array}{c}\text { Molten } \\
\text { temperature } \\
\left({ }^{\circ} \mathbf{C}\right)\end{array}$ & $\begin{array}{c}\text { Cooling } \\
\text { time } \\
(\mathbf{s})\end{array}$ & $\begin{array}{c}\text { Mold } \\
\text { temperature } \\
\left({ }^{\circ} \mathbf{C}\right)\end{array}$ & $\begin{array}{c}\text { 1st stage } \\
\mathbf{P V} \\
\left(\mathbf{m . s}^{-\mathbf{1}}\right)\end{array}$ & $\begin{array}{c}\text { 2nd stage } \\
\mathbf{P V} \\
\left(\mathbf{m}^{-\mathbf{1}}\right)\end{array}$ & $\begin{array}{c}\text { Density } \\
\left(\mathbf{g} \cdot \mathbf{m}^{-\mathbf{3}}\right)\end{array}$ & Defects \\
\hline 178 & 665 & 6.5 & 180 & 0.20 & 6.0 & 2.107 & Sticking \\
178 & 665 & 6.0 & 180 & 0.20 & 6.0 & 2.026 & Sticking \\
178 & 665 & 5.5 & 180 & 0.20 & 6.0 & 2.596 & Ok \\
178 & 665 & 5.0 & 180 & 0.20 & 6.0 & 2.610 & Ok \\
178 & 665 & 4.5 & 180 & 0.20 & 6.0 & 2.515 & Hot tears \\
178 & 665 & 4.0 & 180 & 0.20 & 6.0 & 2.560 & Hot tears \\
\hline
\end{tabular}

Table 13. Optimization of the mold temperature.

\begin{tabular}{|c|c|c|c|c|c|c|c|}
\hline $\begin{array}{c}\text { Injection } \\
\text { pressure } \\
\text { (bar) }\end{array}$ & $\begin{array}{c}\text { Molten } \\
\text { temperature } \\
\left({ }^{\circ} \mathrm{C}\right) \\
\end{array}$ & $\begin{array}{l}\text { Cooling } \\
\text { time } \\
(\mathrm{s})\end{array}$ & $\begin{array}{c}\text { Mold } \\
\text { temperature } \\
\left({ }^{\circ} \mathrm{C}\right)\end{array}$ & $\begin{array}{c}\text { 1st stage } \\
\text { PV } \\
\left(\mathrm{m} . \mathrm{s}^{-1}\right)\end{array}$ & $\begin{array}{c}\text { 2nd stage } \\
\text { PV } \\
\left(\mathrm{m} \cdot \mathrm{s}^{-1}\right)\end{array}$ & $\begin{array}{l}\text { Density } \\
\left(\mathrm{g} \cdot \mathrm{m}^{-\mathbf{3}}\right)\end{array}$ & Defects \\
\hline 178 & 665 & 5.0 & 200 & 0.20 & 6.0 & 2.696 & $\mathrm{Ok}$ \\
\hline 178 & 665 & 5.0 & 205 & 0.20 & 6.0 & 2.607 & $\mathrm{Ok}$ \\
\hline 178 & 665 & 5.0 & 210 & 0.20 & 6.0 & 2.658 & $\mathrm{Ok}$ \\
\hline 178 & 665 & 5.0 & 215 & 0.20 & 6.0 & 2.571 & Sticking \\
\hline 178 & 665 & 5.0 & 220 & 0.20 & 6.0 & 2.569 & Black shade \\
\hline 178 & 665 & 5.0 & 225 & 0.20 & 6.0 & 2.501 & Black shade \\
\hline
\end{tabular}

\subsubsection{Die cooling time}

As per the Taguchi analysis, cooling time has a major effect on the process as compared to other parameters [46]. The graphs of the cooling time against the mean and $S / N$ ratio, as presented in Figures 5 and 6 , reveal a decreasing trend from $4 \mathrm{~s}$ to $6 \mathrm{~s}$ and intersects with the mean line at $4.5 \mathrm{~s}$. Therefore, the optimum value of the cooling time would lie near $4 \mathrm{~s}$. In actual foundry operations, a higher cooling time is preferred to produce parts with fewer defects. To find the optimum value, experiments began with the maximum value of $6.5 \mathrm{~s}$, as mentioned in Table 12.

From the experimental results presented in Table 12 , the optimum cooling time was found to be $5 \mathrm{~s}$, with a resulting density of $2.610 \mathrm{~g} . \mathrm{cm}^{-3}$ and without defects.

\subsubsection{Mold temperature}

The mold temperature does not seem to have any significant effect on the product's density compared to the rest of parameters, as per Taguchi analysis [35]. The graph of the mold temperature plotted against the mean and $S / N$ ratio, as shown in Figures 5 and 6 , is a straight line with a positive gradient, which indicates a direct relationship between the temperature and density of the product. This means that a higher mold temperature will improve the product quality. For an optimum value of mold temperature, experiments were performed by varying the temperature from $200^{\circ} \mathrm{C}$ to $225^{\circ} \mathrm{C}$. Experimental results are mentioned in Table 13.

The optimum value of the mold temperature was $210^{\circ} \mathrm{C}$, as shown in Table 9. Any temperature greater than $210^{\circ} \mathrm{C}$ would result in casting defects.

\subsubsection{1st stage plunger velocity}

Likewise, the 1st stage plunger velocity also does not have any significant effect on the density. The mean and $S / N$ plots, as presented in Figures 5 and 6 , show very infinitesimal changes in response. It is, therefore, concluded that an increase in velocity would decrease the product quality. Experiments were conducted while varying the velocity from $0.20 \mathrm{~m} . \mathrm{s}^{-1}$ to $0.25 \mathrm{~m} . \mathrm{s}^{-1}$, as mentioned in Table 14.

From the response values against the experiments shown in Table 14, it can be stated that the optimum value of the 1 st stage plunger velocity is $0.20 \mathrm{~m} . \mathrm{s}^{-1}$.

\subsubsection{2nd stage plunger velocity}

As per the Taguchi analysis, the 2nd stage plunger velocity significantly affects the density of the product, as is evident from Figures 5 and 6 . The graphs of the means and $S / N$ ratios show an increasing trend from $5 \mathrm{~m} . \mathrm{s}^{-1}$ to $6 \mathrm{~m} . \mathrm{s}^{-1}$, which leads to the conclusion that the optimum velocity lies between $5 \mathrm{~m} . \mathrm{s}^{-1}$ and $6 \mathrm{~m} . \mathrm{s}^{-1}$, as mentioned in Table 15.

The results concluded that the optimum value of $2 \mathrm{nd}$ stage plunger velocity was $6.0 \mathrm{~m} . \mathrm{s}^{-1}$, as per 
Table 14. Optimization of the 1st stage plunger velocity.

\begin{tabular}{|c|c|c|c|c|c|c|c|}
\hline $\begin{array}{l}\text { Injection } \\
\text { pressure } \\
\text { (bar) }\end{array}$ & $\begin{array}{c}\text { Molten } \\
\text { temperature } \\
\left({ }^{\circ} \mathrm{C}\right)\end{array}$ & $\begin{array}{l}\text { Cooling } \\
\text { time } \\
(\mathrm{s})\end{array}$ & $\begin{array}{c}\text { Mold } \\
\text { temperature } \\
\left({ }^{\circ} \mathrm{C}\right)\end{array}$ & $\begin{array}{c}\text { 1st stage } \\
\text { PV } \\
\left(\mathrm{m} . \mathrm{s}^{-1}\right)\end{array}$ & $\begin{array}{c}\text { 2nd stage } \\
\text { PV } \\
\left(\mathrm{m} . \mathrm{s}^{-1}\right)\end{array}$ & $\begin{array}{l}\text { Density } \\
\left(\mathrm{g} \cdot \mathrm{m}^{-\mathbf{3}}\right)\end{array}$ & Defects \\
\hline 178 & 665 & 5.0 & 210 & 0.20 & 6.0 & 2.508 & $\mathrm{Ok}$ \\
\hline 178 & 665 & 5.0 & 210 & 0.20 & 6.0 & 2.292 & Ok \\
\hline 178 & 665 & 5.0 & 210 & 0.20 & 6.0 & 2.392 & Ok \\
\hline 178 & 665 & 5.0 & 210 & 0.25 & 6.0 & 3.392 & Porosity \\
\hline 178 & 665 & 5.0 & 210 & 0.25 & 6.0 & 4.392 & Porosity \\
\hline 178 & 665 & 5.0 & 210 & 0.25 & 6.0 & 5.392 & Porosity \\
\hline
\end{tabular}

Table 15. Optimization of the 2nd stage plunger velocity.

\begin{tabular}{|c|c|c|c|c|c|c|c|}
\hline $\begin{array}{c}\text { Injection } \\
\text { pressure } \\
\text { (bar) }\end{array}$ & $\begin{array}{c}\text { Molten } \\
\text { temperature } \\
\left({ }^{\circ} \mathrm{C}\right) \\
\end{array}$ & $\begin{array}{c}\text { Cooling } \\
\text { time } \\
(\mathrm{s})\end{array}$ & $\begin{array}{c}\text { Mold } \\
\text { temperature } \\
\left({ }^{\circ} \mathrm{C}\right) \\
\end{array}$ & $\begin{array}{c}\text { 1st stage } \\
\text { PV } \\
\left(\mathrm{m} . \mathrm{s}^{-1}\right)\end{array}$ & $\begin{array}{c}\text { 2nd stage } \\
\text { PV } \\
\left(\mathrm{m} . \mathrm{s}^{-1}\right)\end{array}$ & $\begin{array}{l}\text { Density } \\
\left(\mathrm{g} \cdot \mathrm{m}^{-3}\right)\end{array}$ & Defects \\
\hline 178 & 665 & 5.0 & 210 & 0.20 & 5.0 & 2.508 & Pinholes \\
\hline 178 & 665 & 5.0 & 210 & 0.20 & 5.0 & 2.592 & Pinholes \\
\hline 178 & 665 & 5.0 & 210 & 0.20 & 6.0 & 2.592 & Ok \\
\hline 178 & 665 & 5.0 & 210 & 0.20 & 6.0 & 2.592 & Ok \\
\hline 178 & 665 & 5.0 & 210 & 0.20 & 7.0 & 2.592 & Porosity \\
\hline 178 & 665 & 5.0 & 210 & 0.20 & 7.0 & 2.592 & Porosity \\
\hline
\end{tabular}

the data recommendation against a higher molten temperature of $660^{\circ} \mathrm{C}$ given in Table 9 .

\subsubsection{Final experimental results of optimized parameters}

Once all the parameters were optimized through experimentation, a set of optimized parameters was taken, and 30 experiments were performed using these parameters. The response factor and corresponding inspection remarks are listed in Table 16.

From the data, it is evident that the set of parameters used resulted in the optimized parametric solution. A statistical analysis has also been performed on the results of the density presented in Table 16. At a Confidence Interval (CI) of 95\%, the consistency level for the density has been calculated, and is $2.5696<$ $\mu<2.6244$. The Prediction Interval (PI) has also been calculated at a $95 \% \mathrm{CI}$ and is $2.445<P I<2.749$.

To further validate these results, the HPDC of the selected part was carried out using these parameters for a week and data were collected, as shown in Table 17.

Prior to this optimization, almost $0.90 \%$ of the total production was getting rejected because of porosity/pin holes. The production data, after implementing the optimized parameters, showed that $0.29 \%$ of the total production got rejected because of porosity, which indicates a reduction of almost $61 \%$ in rejection rate. In addition to that, a decrease from $32.17 \%$ to $11.47 \%$ was also recorded in the defects' percentage of porosity, as is evident from Table 17. The comparison of onemonth production data given in Tables 17 and 3 also showed that the optimized parameters had a significant effect on some of other defects as well. After the use of optimized parameters, a $16 \%$ reduction in rejection rate due to crack and a $10 \%$ reduction in rejection rate due to inclusions were also observed. However, the optimized parameters did not have any effect on the reduction in rejection rates due to shrinkage, dents, ring crack/mismatch, and shades.

The collected data, after using the optimized values of the significant process parameters, are presented in Table 17. To illustrate their significance, this data is plotted on a Pareto diagram, as shown in Figure 7. It can be concluded both from Table 17 and Figure 7 that the parts rejected due to porosity and blow holes were significantly reduced, i.e., from 435 to only 140 . This is a clear evidence of the effectiveness of this research.

\subsection{Comparison of the DOE versus experimental results}

The values of optimized parameters were mainly found close to the results of experiments, leading to a conclusion that each selected parameter had its own effect on the product quality. The comparison between the experimental and DOE results is listed in Table 18.

Each parameter had its own influence on the 
Table 16. Results of the optimized parametric solution.

\begin{tabular}{|c|c|c|c|c|c|c|c|}
\hline $\begin{array}{c}\text { Injection } \\
\text { pressure } \\
(\text { bar })\end{array}$ & $\begin{array}{c}\text { Molten } \\
\text { temperature } \\
\left({ }^{\circ} \mathrm{C}\right)\end{array}$ & $\begin{array}{c}\text { Cooling } \\
\text { time } \\
(\mathrm{s})\end{array}$ & $\begin{array}{c}\text { Mold } \\
\text { temperature } \\
\left({ }^{\circ} \mathrm{C}\right)\end{array}$ & $\begin{array}{c}\text { 1st stage } \\
\text { PV } \\
\left(\mathrm{m} . \mathrm{s}^{-1}\right)\end{array}$ & $\begin{array}{c}\text { 2nd stage } \\
\text { PV } \\
\left(\mathrm{m} . \mathrm{s}^{-1}\right)\end{array}$ & $\begin{array}{l}\text { Density } \\
\left(\mathrm{g} \cdot \mathrm{m}^{-3}\right)\end{array}$ & Defects \\
\hline 178 & 665 & 5.0 & 210 & 0.20 & 6.0 & 2.507 & OK \\
\hline 178 & 665 & 5.0 & 210 & 0.20 & 6.0 & 2.589 & OK \\
\hline 178 & 665 & 5.0 & 210 & 0.20 & 6.0 & 2.567 & OK \\
\hline 178 & 665 & 5.0 & 210 & 0.20 & 6.0 & 2.599 & OK \\
\hline 178 & 665 & 5.0 & 210 & 0.20 & 6.0 & 2.499 & OK \\
\hline 178 & 665 & 5.0 & 210 & 0.20 & 6.0 & 2.589 & OK \\
\hline 178 & 665 & 5.0 & 210 & 0.20 & 6.0 & 2.568 & OK \\
\hline 178 & 665 & 5.0 & 210 & 0.20 & 6.0 & 2.590 & OK \\
\hline 178 & 665 & 5.0 & 210 & 0.20 & 6.0 & 2.601 & OK \\
\hline 178 & 665 & 5.0 & 210 & 0.20 & 6.0 & 2.511 & OK \\
\hline 178 & 665 & 5.0 & 210 & 0.20 & 6.0 & 2.600 & OK \\
\hline 178 & 665 & 5.0 & 210 & 0.20 & 6.0 & 2.614 & OK \\
\hline 178 & 665 & 5.0 & 210 & 0.20 & 6.0 & 2.655 & OK \\
\hline 178 & 665 & 5.0 & 210 & 0.20 & 6.0 & 2.860 & OK \\
\hline 178 & 665 & 5.0 & 210 & 0.20 & 6.0 & 2.567 & OK \\
\hline 178 & 665 & 5.0 & 210 & 0.20 & 6.0 & 2.532 & OK \\
\hline 178 & 665 & 5.0 & 210 & 0.20 & 6.0 & 2.529 & OK \\
\hline 178 & 665 & 5.0 & 210 & 0.20 & 6.0 & 2.514 & OK \\
\hline 178 & 665 & 5.0 & 210 & 0.20 & 6.0 & 2.689 & OK \\
\hline 178 & 665 & 5.0 & 210 & 0.20 & 6.0 & 2.710 & OK \\
\hline 178 & 665 & 5.0 & 210 & 0.20 & 6.0 & 2.689 & OK \\
\hline 178 & 665 & 5.0 & 210 & 0.20 & 6.0 & 2.588 & OK \\
\hline 178 & 665 & 5.0 & 210 & 0.20 & 6.0 & 2.541 & OK \\
\hline 178 & 665 & 5.0 & 210 & 0.20 & 6.0 & 2.597 & OK \\
\hline 178 & 665 & 5.0 & 210 & 0.20 & 6.0 & 2.554 & OK \\
\hline 178 & 665 & 5.0 & 210 & 0.20 & 6.0 & 2.576 & OK \\
\hline 178 & 665 & 5.0 & 210 & 0.20 & 6.0 & 2.590 & OK \\
\hline 178 & 665 & 5.0 & 210 & 0.20 & 6.0 & 2.654 & OK \\
\hline 178 & 665 & 5.0 & 210 & 0.20 & 6.0 & 2.640 & OK \\
\hline 178 & 665 & 5.0 & 210 & 0.20 & 6.0 & 2.599 & OK \\
\hline
\end{tabular}

Table 17. One-month production data using optimized parameters.

\begin{tabular}{clccc}
\hline Sr. No & \multicolumn{1}{c}{ Defects } & Rejected qty. & Rejected qty. percentage & Defects percentage \\
\hline 1 & Pin hole/blow hole & 140 & $0.29 \%$ & $11.47 \%$ \\
2 & Crack & 160 & $0.33 \%$ & $13.10 \%$ \\
3 & Shrinkage & 189 & $0.39 \%$ & $15.48 \%$ \\
4 & Inclusion & 116 & $0.24 \%$ & $9.50 \%$ \\
5 & Dents & 216 & $0.44 \%$ & $17.70 \%$ \\
6 & Ring crack/mismatch & 206 & $0.42 \%$ & $16.88 \%$ \\
7 & Shade & 194 & $0.4 \%$ & $15.89 \%$ \\
\hline
\end{tabular}

HPDC product quality. The detailed comparison presented in Table 18 clearly shows the difference between the DOE and experimental results, i.e., $1.11 \%$ in injection pressure, $0.75 \%$ in molten temperature, $25 \%$ in cooling time, and no difference in mold temperature or 1st and 2nd stage plunger velocity. In comparison, the cooling time exhibited the highest difference, while the mold temperature, 1st stage plunger velocity, and 2nd stage plunger velocity matched exactly with the experimental results. 


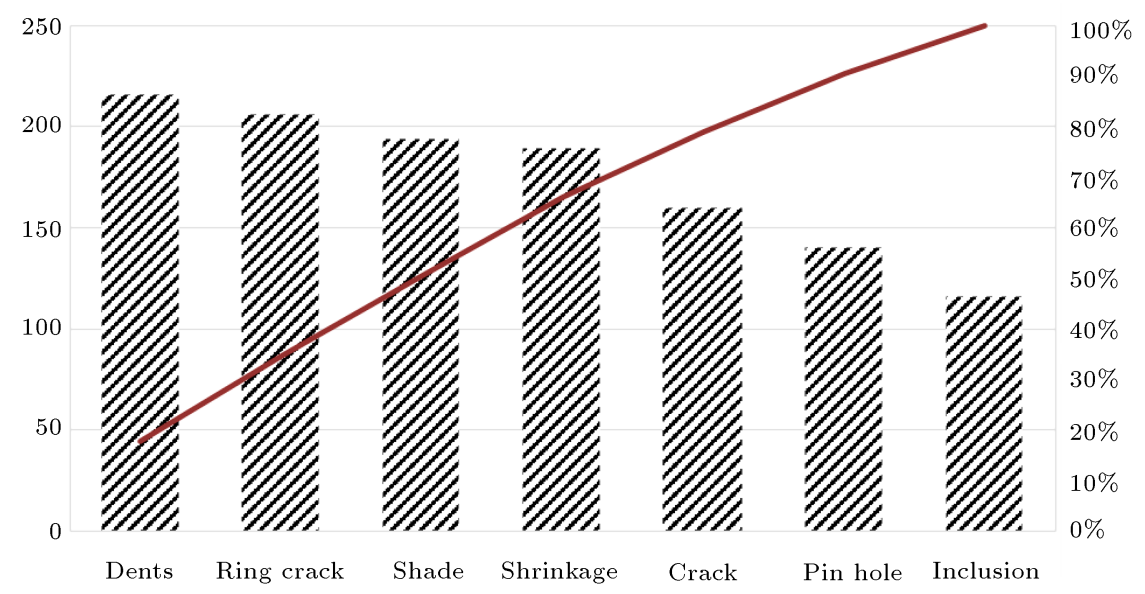

Figure 7. Pareto chart of the defects after optimization.

Table 18. Comparison between the Design Of Experimental (DOE) and experimental results.

\begin{tabular}{|c|c|c|c|c|c|c|}
\hline Parameters & $\begin{array}{c}\text { Injection } \\
\text { pressure } \\
\text { (bar) }\end{array}$ & $\begin{array}{c}\text { Molten } \\
\text { temperature } \\
\left({ }^{\circ} \mathrm{C}\right)\end{array}$ & $\begin{array}{l}\text { Cooling } \\
\text { time } \\
\text { (s) }\end{array}$ & $\begin{array}{c}\text { Mold } \\
\text { temperature } \\
\left({ }^{\circ} \mathrm{C}\right)\end{array}$ & $\begin{array}{c}\text { 1st stage } \\
\text { PV } \\
\left(\mathrm{m} . \mathrm{s}^{-1}\right)\end{array}$ & $\begin{array}{c}\text { 2nd stage } \\
\text { PV } \\
\left(\mathrm{m} . \mathrm{s}^{-1}\right)\end{array}$ \\
\hline DOE & 180 & 670 & 4.0 & 210 & 0.2 & 6.0 \\
\hline Exp. results & 178 & 665 & 5.0 & 210 & 0.2 & 6.0 \\
\hline Delta & $2.0(\downarrow)$ & $5.0(\downarrow)$ & $1.0(\uparrow)$ & $0(-)$ & $0(-)$ & $0(-)$ \\
\hline$\%$ increase \& decrease & $1.11 \%$ & $0.75 \%$ & $25.0 \%$ & $0.0 \%$ & $0.0 \%$ & $0.0 \%$ \\
\hline
\end{tabular}

\section{Conclusion}

High-Pressure Die Casting (HPDC) is an important manufacturing process that can produce castings in large quantities with a significant amount of cost saving. Despite having this advantage, the process is susceptible to different defects like porosity, pinholes, blow holes, sticking, cracks, inclusions, etc. The occurrence of these defects can be controlled by using the optimized combination of the values of different process parameters, e.g., injection pressure, molten metal temperature, die cooling time, mold temperature, 1st stage plunger velocity, and 2nd stage plunger velocity. An approach using Design Of Experiment (DOE) in combination with a Taguchi analysis was, therefore, developed during this research to optimize these process parameters and minimize the casting defects. To showcase the effectiveness of the proposed approach, the HPDC process in a motorbike manufacturing company in Lahore (Pakistan) was selected. For experimentation and comparison, a major defect (porosity) that was occurring frequently was selected to be minimized while maximizing the response factor (density) of a part (Crankcase LH) produced through HPDC. From the Taguchi analysis followed by experimental designs, it was found that the cooling time, injection pressure, and 2 nd stage plunger velocity had the most significant effects on the response factor (density). A reduction in the percentage of defects was obtained while using a 178 -bar injection pressure, $665^{\circ} \mathrm{C}$ molten temperature, $5 \mathrm{~s}$ cooling time, $210^{\circ} \mathrm{C}$ mold temperature, $0.20 \mathrm{~m} . \mathrm{s}^{-1}$ 1st stage plunger velocity, and $6.0 \mathrm{~m} / \mathrm{s}$ 2nd state plunger velocity. These optimized parameters caused the overall decrease of almost $61 \%$ in the rejection rate of the selected part due to porosity.

\section{References}

1. Teng, X., Mae, H., Bai, Y., et al. "Pore size and fracture ductility of aluminum low pressure die casting", Eng. Fract. Mech., 76(8), pp. 983-996 (2009).

2. Fracchia, E., Lombardo, S., and Rosso, M. "Case study of a functionally graded aluminum part", Appl. Sci., 8(7), p. 1113 (2018).

3. Makhlouf, M.M., Apelian, D., and Wang, L., Microstructures and Properties of Aluminum Die Casting Alloys, USDOE Idaho Operations Office, Idaho Falls, ID (US); North American Die ... (1998).

4. Dargusch, M.S., Dour, G., Schauer, N., et al. "The influence of pressure during solidification of high pressure die cast aluminium telecommunications components", J. Mater. Process. Technol., 180(1-3), pp. 37-43 (2006).

5. Bonollo, F., Gramegna, N., and Timelli, G. "Highpressure die-casting: contradictions and challenges", Jom, 67(5), pp. 901-908 (2015). 
6. Hamasaiid, A., Dargusch, M.S., Davidson, C., et al. "Effect of mold coating materials and thickness on heat transfer in permanent mold casting of aluminum alloys", Metall. Mater. Trans. A, 38, pp. 1303-1316 (2007).

7. Adamane, A.R., Arnberg, L., Fiorese, E., et al. "Influence of injection parameters on the poorosity and tensile properties of high-pressure die cast Al-Si alloys: A review", Int. J. Met., 9(1), pp. 43-53 (2015).

8. Hidalgo, R., Esnaola, J., Larrañaga, M., et al. "Influence of surface finish and porosity on the fatigue behaviour of A356 Aluminium casting alloy", MATEC Web Conf., 165, p. 14007 (2018).

9. Anilchandra, A.R., Arnberg, L., Bonollo, F., et al. "Evaluating the tensile properties of aluminum foundry alloys through reference castings-A review", Materials (Basel)., 10(9), p. 1011 (2017).

10. Yang, H., Yu, W., LI, X., et al. "Effect of different processing parameters on interfacial heat-transfer behavior in high-pressure die-casting process", Trans. Nonferrous Met. Soc. China, 28, pp. 2599-2606 (2018).

11. Kong, L.X., She, F.H., Nahavandi, S., et al. "Die temperature monitoring of high pressure die casting", Smc 2000 Conference Proceedings, 2000 Ieee International Conference on Systems, Man and Cybernetics, Cybernetics Evolving to Systems, Humans, Organizations, and Their Complex Interactions, 3, pp. 1756-1761 (2000).

12. Syrkos, G. "Die casting process optimization using Taguchi methods", J. Mater. Process. Technol., 135, pp. 68-74 (2003).

13. Ingle, V. and Sorte, M.B. "Defects, root causes in casting process and their remedies: Review", Int. J. Eng. Res. Appl., 07, pp. 47-54 (2017).

14. Zyska, A., Konopka, Z., Lagiewka, M., et al. "Porosity of castings produced by the vacuum assisted pressure die casting method", Archives of Foundry Engineering, 15(1), pp. 125-130 (2015).

15. Apparao, K.C. and Birru, A.K. "QFD-Taguchi based hybrid approach in die casting process optimization", Trans. Nonferrous Met. Soc. China, 27(11), pp. 23452356 (2017).

16. Wang, Y., Shiping, W., Lianjie, N., et al. "Optimization of low-pressure die casting process parameters for reduction of shrinkage porosity in ZL205A alloy casting using Taguchi method", Proc. Inst. Mech. Eng. Part B J. Eng. Manuf., 228, pp. 1508-1514 (2014).

17. Kwon, H.-J. and Kwon, H.-K. "Computer aided engineering $(\mathrm{CAE})$ simulation for the design optimization of gate system on high pressure die casting (HPDC) process", Robot. Comput. Integr. Manuf., 55, pp. 147153 (2019).

18. Yalçın, B., Koru, M., Ipek, O., et al. "Effect of injection parameters and vacuum on the strength and porosity amount of die-casted A380 alloy", International Journal of Metalcasting, 11(2), pp. 195-206 (2017).
19. Fiorese, E., Bonollo, F., and Battaglia, E. "A tool for predicting the effect of the plunger motion profile on the static properties of aluminium high pressure die cast components", Metals (Basel)., 8(10), p. 798 (2018).

20. Cao, H., Wang, C., Che, J., et al. "Effect of flow state of pure aluminum and A380 alloy on porosity of high pressure die castings", Materials (Basel), 12(24), p. 4219 (2019).

21. Iwata, Y., Dong, S., Sugiyama, Y., et al. "Effects of solidification behavior during filling on surface defects of aluminum alloy die casting", Mater. Trans., 54, pp. 1944-1950 (2013).

22. Sadeghi, M. and Mahmoudi, J. "Experimental and theoretical studies on the effect of die temperature on the quality of the products in high-pressure diecasting process", Adv. Mater. Sci. Eng., 2012, p. 434605 (2012).

23. Liu, C., Jiao, X., Nishat, H., et al. "Characteristics of Fe-rich intermetallics compounds and their influence on the cracking behavior of a newly developed high-pressure die cast $\mathrm{Al}-4 \mathrm{Mg}-2 \mathrm{Fe}$ alloy", J. Alloys Compd., 854, p. 157121 (2021).

24. Kumar, S., Satsangi, P., and Prajapati, D.R. "Optimization of green sand casting process parameters of a foundry by using Taguchi's method", The International Journal of Advanced Manufacturing Technology, 55, pp. 23-34 (2010).

25. Fajkiel, A., Dudek, P., Walczak, W., et al. "Improvement of quality of a gravity die casting made from aluminum bronze be application of numerical simulation", Arch. Foundry Eng., 7, pp. 11-14 (2007).

26. Świłło, S. and Myszka, D. "Archives of $39 / 3$ advanced metrology of surface defects measurement for aluminum die casting", Archives of Foundry Engineering, 11(3), pp. 227-230 (2011).

27. Cica, D. and Kramar, D. "Intelligent process modeling and optimization of porosity formation in highpressure die casting", International Journal of Metalcasting, 12, pp. 814-824 (2018).

28. Cao, H., Shen, C., Wang, C., et al. "Direct observation of filling process and porosity prediction in high pressure die casting", Mater. (Basel, Switzerland), 12(7), p. 1099 (2019).

29. Aamir, M., Tu, S., Tolouei-Rad, M., et al. "Optimization and modeling of process parameters in multihole simultaneous drilling using Taguchi method and fuzzy logic approach", Materials (Basel), 13(3), p. 680 (2020).

30. Do, T.-V. and Hsu, Q.-C. "Optimization of minimum quantity lubricant conditions and cutting parameters in hard milling of AISI H13 steel", Appl. Sci., 6(3), p. 83 (2016).

31. Vu, N.-P., Nguyen, Q.-T., Tran, T.-H., et al. "Optimization of grinding parameters for minimum grinding time when grinding tablet punches by $\mathrm{CBN}$ wheel on CNC milling machine", Applied Sciences, 9(5) (2019). 
32. Lan, T.-S., Chuang, K.-C., and Chen, Y.-M. "Optimization of machining parameters using fuzzy Taguchi method for reducing tool wear", Appl. Sci., 8(7), p. 1011 (2018).

33. Kolahan, F. and Azadi Moghaddam, M. "The use of Taguchi method with grey relational analysis to optimize the EDM process parameters with multiple quality characteristics", Sci. Iran., 22(2), pp. 530-538 (2015).

34. Azadi Moghaddam, M. and Kolahan, F. "Modeling and optimization of the electrical discharge machining process based on a combined artificial neural network and particle swarm optimization algorithm", Sci. Iran., 27(3), pp. 1206-1217 (2020).

35. Karthik, A., Karunanithi, R., Srinivasan, S.A., et al. "The optimization of squeeze casting process parameter for AA2219 alloy by using the Taguchi method", Materials Today: Proceedings, 27, pp. 2556-2561 (2020).

36. Hassasi, S.A., Abbasi, M., and Hosseinipour, S.J. "Parametric investigation of squeeze casting process on the microstructure characteristics and mechanical properties of A390 aluminum alloy", Int. J. Met., 14(1), pp. 69-83 (2020).

37. Souissi, N., Souissi, S., Niniven, C., et al. "Optimization of squeeze casting parameters for 2017 a wrought Al alloy using Taguchi method", Metals (Basel), 4(2), pp. 141-154 (2014).

38. Prabhakar, A., Papanikolaou, M., Salonitis, K., et al. "Minimising defect formation in sand casting of sheet lead: A DoE approach", Metals (Basel), 10(2), p. 252 (2020).

39. Mohsin, I., He, K., Li, Z., et al. "Optimization of the polishing efficiency and torque by using Taguchi method and ANOVA in robotic polishing", Appl. Sci., 10(3), p. 824 (2020).

40. Balikai, V.G., Siddlingeshwar, I.G., and Gorwar, M. "Optimization of process parameters of High Pressure Die Casting process for ADC12 Aluminium alloy using Taguchi method", Int. J. Pure Appl. Math., 120(6), pp. 959-969 (2018).

41. Sarin, S. "Teaching Taguchi's approach to parameter design", Quality Progress, 30(5), p. 102 (1997). 30 (1997).

42. Wu, C.C. and Su, T.S. "Application of the Taguchi method for the optimization of visual inspection parameters for multi-layer ceramic capacitors", Sci. Iran., 21(6), pp. 2379-2386 (2014).

43. Chang, M.S. "Use of Taguchi method to develop a robust design for the magnesium alloy die casting process", Mater. Sci. Eng. A, 379(1-2), pp. 366-371 (2004).

44. Kamaruddin, S., Khan, Z., and Foong, S. "Application of Taguchi method in the optimization of injection moulding parameters for manufacturing products from plastic blend", Int. J. Web Eng. Technol., 2, pp. 574580 (2010).
45. Asim, M., Khan, M., Khan, L., and Umer, M. "An integrated approach of quality for polymer composite manufacturing validated and optimized through Taguchi method", Sci. Iran., 24, pp. 1985-1995 (2017).

46. Banik, K. "Effect of mold temperature on short and long-term mechanical properties of PBT", Express Polym. Lett.-Express Polym Lett., 2, pp. 111-117 (2008).

\section{Biographies}

Surkhail Tariq has received his BSc degree in Mechanical Engineering from University of Lahore, Pakistan. He has recently completed his MS in Mechanical Engineering from University of Wah, Pakistan. During his MS research, Surkhail Tariq worked on optimization of high-pressure die casting process and his research work is entitled as "Minimizing the Casting Defects in High Pressure Die Casting Process". His research interests include modeling and optimization of manufacturing processes. He has one year working experience in S.T. Engineering Services (Pvt) Ltd, Lahore.

Adnan Tariq is serving as an Associate Professor/Chairperson at the Department of Mechanical Engineering, Wah Engineering College, University of Wah, Pakistan. He received his BSc degree in Mechanical Engineering from University of Engineering \& Technology, Peshawar, Pakistan in 1993. He further graduated with an MS degree in 2004 and $\mathrm{PhD}$ degree in 2010 in Manufacturing Systems from the College of Electrical and Mechanical Engineering (E \& ME), National University of Science \& Technology (NUST), Rawalpindi, Pakistan. Dr. Tariq's research interests include Design and Scheduling of Manufacturing Systems in general and Cellular Manufacturing Systems in particular. Scheduling of Job Shops and Flow Shops, application of GA, SA, PSO, and other heuristic based approaches to design and schedule manufacturing systems and manufacturing process optimization remained his major focus areas. He has published several articles in these areas in different international journals and conferences.

Manzar Masud is serving as a Lecturer at the Department of Mechanical Engineering, Capital University of Science and Technology, Pakistan. He has received his BSc degree in aerospace engineering from Institute of Space Technology, Pakistan and MS degree in Mechanical Engineering from HITEC University, Pakistan. He is now a PhD candidate at the Department of Mechanical Engineering at School of Mechanical and Manufacturing Engineering, National University of Science and Technology, Pakistan. His research inter- 
ests include optimization of manufacturing processes, computational mechanics, and mechanics of composite materials.

Zabdur Rehman is serving as Assistant Professor at the Department of Mechanical Engineering, Air University Aerospace and Aviation Campus, Kamra,
Pakistan. He received his BS degree in Mechanical Engineering from Ghulam Ishaq Khan Institute, Pakistan and $\mathrm{MS}$ leading to $\mathrm{PhD}$ degree in Mechanical Engineering from Dongguk University, Seoul, South Korea. His research interests include optimization of manufacturing processes, computational fluid dynamics, and gas hydrate. 